\title{
Flowering and fruiting of Aulonemia aristulata: a gynomonoecious woody bamboo species from Atlantic Forest in Brazil
}

\author{
MARIA TEREZA GROMBONE-GUARATINI ${ }^{1,3}$, ANDRESSA ALENCAR DO NASCIMENTO ${ }^{1} \mathrm{e}$ \\ ANA PAULA SANTOS-GONÇALVES ${ }^{2}$
}

(received: May 13, 2010; accepted: January 27, 2011)

\begin{abstract}
Flowering and fruiting of Aulonemia aristulata: a gynomonoecious woody bamboo species from Atlantic Forest in Brazil). Aulonemia aristulata (Döll) McClure is a lignified bamboo species endemic to Brazil. This species occurs in southeastern forests and can reach high density at forest edges, dominating the understory of canopy-disturbed forest patches. The goal of this study was to describe the flowering period, floral biology, fruiting and seedling recruitment of $A$. aristulata in natural conditions in two areas located in a segment of the Atlantic Forest. Data on the morphology of the synflorescences and florets, timing and sequence of the anthesis events and floral visitors were recorded. Natural pollinators (open pollination or control) as well as spontaneous self-pollination were also checked. Pollen viability was estimated using the acetocarmine technique. Aulonemia aristulata is monocarpic (semelparous) with gregarious flowering. All culms in both studied areas blossomed and fruited between August and November 2007, dying subsequently between December 2007 and April 2008. Two types of synflorescences and flowers were observed: terminal with bisexual and protandric florets, with the anthesis lasting for 3-4 days; and axillary, with morphologically bisexual, but functionally female, florets and anthesis lasting for 3-4 days. The latter were also observed in the rhizome of plants whose aerial portion had been removed. The presence of axillary synflorescences with pistillate flowers is described here for the first time in Aulonemia species. Moreover, this is the first report of gynomonoecy in woody bamboo. Fruiting from bisexual florets under natural conditions (35\%) was superior to that obtained from bagged synflorescences (11.5\%). Fruiting from functional female florets was around $20 \%$. Pollen viability was on the average of $90 \%$. The results suggest that Aulonemia aristulata is anemophilous. The massive bamboo seedling recruitment observed after dieback with the ability to colonize open areas could promote the regeneration of Aulonemia aristulata.
\end{abstract}

Key words - floral biology, gregarious flowering, gynomonoecy, protandry, tropical forest

RESUMO - (Floração e frutificação de Aulonemia aristulata: uma espécie de bambu lignificado ginomonoica da Floresta Atlântica no Brasil). Aulonemia aristulata (Döll) McClure é uma espécie de bambu lignificado endêmico do Brasil. Esta espécie ocorre em florestas do sudeste e pode atingir altas densidades em bordas de floresta e dominar o sub-bosque de manchas de floresta que tiveram o dossel perturbado. O objetivo deste estudo foi descrever o período de florescimento, a biologia floral, a frutificação e o recrutamento de plântulas de A. aristulata, em condições naturais, em duas áreas localizadas em um segmento de Floresta Atlântica. Foram registrados dados sobre a morfologia das sinflorescências e das espiguetas, tempo e sequência de eventos de antese e visitantes florais. Foram também verificadas a polinização natural (polinização aberta e controle) e a autopolinização espontânea. A viabilidade do pólen foi estimada usando a técnica de acetocarmim. Aulonemia aristulata é monocárpica (semélpara) com floração gregária. Todos os colmos em ambas as populações estudadas floresceram e frutificaram entre agosto e novembro de 2007 e, subsequentemente, morreram entre dezembro de 2007 e abril de 2008. Dois tipos de sinflorescências foram observadas: terminais com antécios bissexuais e protândricos com antese de 3-4 dias e axilares com antécios bissexuais, mas funcionalmente femininos e com antese de 3-4 dias. As últimas foram observadas no rizoma de plantas das quais a porção aérea foi removida. A presença de sinflorescências axilares com flores pistiladas é descrita aqui pela primeira vez em espécies de Aulonemia. Além disso, este é o primeiro relato de ginomonoicia em bambus lignificados. A frutificação sob condições naturais (35\%) foi superior à obtida nas sinflorescências ensacadas (11,5\%). A produção de frutos originados das flores femininas foi cerca de $20 \%$. A viabilidade do pólen foi de cerca de $90 \%$. O conjunto de resultados obtidos sugere que Aulonemia aristulata é anemófila. O recrutamento massivo de plântulas, observado após a morte, associado à habilidade de colonizar áreas abertas poderá promover a regeneração de Aulonemia aristulata.

Palavras-chave - biologia floral, floração gregária, floresta tropical, ginomonoicia, protandria

1. Instituto de Botânica, Núcleo de Pesquisa em Ecologia, Caixa Postal 3005, 01031-970 São Paulo, SP, Brazil.

2. Universidade Federal de Viçosa, Departamento de Biologia Vegetal, Campus Universitário. Av. P. H. Rolphs, s/n., 36570-000 Viçosa, MG, Brazil.

3._Autor para correspondência: mgromboneguaratini@gmail.com

\section{Introduction}

Bamboos are members of the Bambusoideae (Poaceae) subfamily and they are divided into two tribes. The first, Bambuseae, includes woody bamboos 
and encompasses about 1,300 species, while the second, Olyreae, includes the herbaceous bamboos, comprising about 110 species (Clark et al. 1995, Judziewicz et al. 1999).

Brazil has the largest bamboo diversity in the New World, housing $89 \%$ of the genera and $65 \%$ of the known bamboo species (Filgueiras \& Santos-Gonçalves 2004). Understory bamboos are a very important component of the Atlantic Forest (Filgueiras 1988).

Bamboos are plants that display rapid biomass growth after long periods of exclusively vegetative growth (Griscom \& Ashton, 2003, 2006), culminating in explosive flowering followed by widespread population death. The synchronized flowering and dieback of monocarpic bamboos normally reset the regeneration process by creating an opportunity for germination and growth of canopy species (Giordano et al. 2009). Nevertheless some studies consider the massive bamboo seedling recruitment after reproduction an efficient strategy to suppress or delay the recruitment and colonization of tree species and the growth of adult trees (Griscom \& Ashton 2003).

Floral characters observed in reproductive biology studies have shown that in some bamboo species the gynoecium matures earlier than the androecium (Ramanayake \&Yakandawala 1998, Huang et al. 2002) while in others both, the gynoecium and the androecium mature at the same time (John \& Nadgauda 2002). Protandrous florets (the androecium matures earlier than the gynoecium) are rare in bamboos (Ramanayake \& Weerawardene 2003). The presence of seed set in enclosed synflorescences and embryo development in a few fruits indicates that apomixis is also possible in bamboo species (Nadgauda et al. 1993, Ramanayake \& Weerawardene 2003).

Due to the long intermast period for the mass flowering of the majority of bamboo species (Janzen 1976), very few reports have investigated their sexual reproduction. Among the Brazilian species, only the woody bamboos Actinocladum verticillatum (Nees) McClure (Filgueiras \& Pereira 1988) and Merostachys riedeliana Döll (Guilherme \& Ressel 2001) have been studied with respect to reproductive biology. In both species, frequent visits from bees of the Trigona genus, which may act as pollinators, were documented. Merostachys riedeliana is also anemophilous and selfcompatible.

Aulonemia Goudot is a genus of woody bamboo comprising about 32 species that occur in forest environments in mountain ranges of South and Central Americas (Judziewicz et al. 1999). In the state of
São Paulo, Aulonemia is represented by two species: Aulonemia aristulata (Döll) McClure and Aulonemia fimbriatifolia L. G. Clark (Clark 2001, 2004). Aulonemia aristulata is one of the threatened species of the state of São Paulo (Mamede et al. 2007). In general, this species shows discontinuous and low density populations, but can reach high density at forest edges and dominate the understory of canopy-disturbed forest patches. The substantial biomass of this bamboo species, which forms large tussocks due to the voluminous underground net of rhizomes, apparently has a negative effect on the survival of other arboreal species in the Parque Estadual das Fontes do Ipiranga (PEFI).

The purpose of this study was to describe not yet known flowering period, floral biology, fruiting, and seedling recruitment of $A$. aristulata in the Atlantic Forest in Brazil. Moreover, floral visitors, natural pollination (open pollination or control) and spontaneous self-pollination were also checked.

\section{Material and methods}

Study area - The study was carried out at the Parque Estadual das Fontes do Ipiranga (PEFI), an urban isolated tropical forest fragment ( $c a 530$ ha) located in São Paulo, SE Brazil (2338'40" S, 46³6’38' W; 770-825 m.a.s.l.). The area is part of the São Paulo Green Belt Biosphere. The regional climate is classified as Köppen's Cwb type (1948) (i.e., temperate with a rainy summer and dry winter) (Santos $\&$ Funari 2002). Average maximum and minimum annual temperatures are $22.4^{\circ} \mathrm{C}$ (February) and $15.7^{\circ} \mathrm{C}$ (July), respectively. Annual preciptation averages $1,540 \mathrm{~mm}$, with less than $100 \mathrm{~mm}$ of monthly precipitation from April to September (Santos \& Funari 2002). The predominant soils are latosols according to the Brazilian Soil Classification System (Embrapa 1999).

Two non-contiguous sites within the PEFI were selected for this study. Past disturbances, such as logging, fire, and partial deforestation resulted in discontinuous canopy areas (Pivello \& Peccinini 2002) that potentially promoted the colonization of bamboo species into open forest patches. These sites exhibit a predominance of $A$. aristulata in the understory (up to $4 \mathrm{~m}$ height), an open canopy and a low tree density.

Study species - Aulonemia aristulata (Döll) MacClure is endemic to Brazil and occurs in the central and southeastern regions in umbrophilic and seasonal forests (Peter L. Viana, personal communication). According to Clark (2001), A. aristulata is characterized by displaying amphimorph rhizomes, decumbent or scandent culms with 1-4 m, hollow internodes, and nodes at mid-culm with a single bud resulting in a branch complement with only one dominant branch. The inflorescences are terminal and form a panicle 
(synflorescence), with spikelets containing bisexual florets and strongly maculate and aristate lemma. Voucher species were deposited in the Herbarium SP (Instituto de Botânica de São Paulo).

Flowering, fruiting periods, floral morphology and biologyThe flowering time (months in which the species was in flower), the blooming peak (months in which more than $50 \%$ of the culms of species were in flower) and fruiting were recorded weekly from August 2007 to April 2008. To follow flowering phenology, 30 culms $10 \mathrm{~m}$ distant from each other were tagged. Morphology was analyzed in fresh flowers after storage in $70 \%$ ethanol. Florets were examined daily from September 20 to October 15,2007 . The anthesis and the longevity of 80 florets from 16 individuals ( $n=8$ per area) were registered. Period of stigma receptivity was recorded; they were considered receptive if they were turgid (sensu Taylor \& Qin 1988). The number of spikelets per synflorescence $(n=20)$ and the number of florets per spikelet $(n=20)$ were counted; the lengths of spikelets $(n=20)$, anthers $(n=25)$, stigmas $(n=12)$ and fruits were also measured under a stereomicroscope. The coloration of anthers was recorded, and the production of fruits was monitored. Pollen from ten anthers was collected from ten randomly collected florets on October 8, 2007. Pollen viability was estimated using the acetocarmine technique (Radford et al. 1974). A hundred pollens grains were counted from each anther, and grains that stained with acetocarmine were considered viable.

In August 2007, individuals with a suppressed aerial part (due to pruning, commonly carried out in the PEFI for maintenance and cleaning) produced synflorescences from the rhizome (axillary synflorescences). Morphology was analyzed in fresh flowers after storage in $70 \%$ ethanol. The anthesis and the longevity of 60 florets from 10 individuals were registered. The period of stigma receptivity was recorded. The number of synflorescences $(n=25)$, spikelets per synflorescence $(n=25)$ and the number of florets per spikelet $(n=25)$ were counted; the lengths of spikelets $(n=25)$, anthers $(n=25)$, stigmas $(n=25)$ and fruits were also measured. The coloration of anthers was recorded, and the production of fruits was monitored. Pollen from ten anthers was collected from ten randomly collected florets on November 23, 2007. Pollen viability was estimated using the acetocarmine technique (Radford et al.1974). To verify whether the production of these synflorescences was related to the suppression of the aerial portion of the plants, we cultivated rhizomes in a greenhouse located in the Núcleo de Pesquisa em Fisiologia e Bioquímica, Instituto de Botânica (SP, Brazil).

Breeding system - Thirty terminal synflorescences (approximately 3,500 florets) were tagged to verify natural fruit set (open pollination or control). For spontaneous selfpollination, 30 synflorescences (about 3,500 florets in preanthesis) were bagged at the bud stage.
Visitors - Visitors were observed in the field in 90 randomly distributed culms (45 per study area). Floral visitors were observed during $30 \mathrm{~h}$ (for 15 non-consecutive days) from $07 \mathrm{~h} 00 \mathrm{am}$ to $05 \mathrm{~h} 00 \mathrm{pm}$ to record the species, their frequency and their behavior during the visits.

Seed recruitment - To verify seed recruitment, we established five randomly distributed plots of $1 \times 1 \mathrm{~m}$ in July 2008 and recorded each new recruited seedling.

\section{Results}

Aulonemia aristulata started to flower in the first two weeks of August 2007. Almost 100\% of the branches present in both studied populations blossomed and bore fruit between September and November 2007, before subsequently dying between December 2007 and April 2008. Flowering was observed during the late dry season, when strong winds may favor the pollination. Mast seeding started with the rainy season.

The plants produced two types of synflorescences. The first was terminal with bisexual and protandric florets with a 3-4 day anthesis and the second was axillary with bisexual, but functionally female, florets. The floral attributes are displayed in table 1.

In terminal synflorescences, the anthesis of bisexual florets was basipetal. In general, the anthesis of each floret lasted 3-4 days. In the first two days, the opening occurred between 06h00-07h00 am, when the anthers were exposed from florets. The three yellow anthers, supported by long filaments, were pendulous and poricidal, with apical pores. The anthers released pollen when moved by the wind. After pollen release, the stamens dried up. On the second day, around 06h3007h00 am, the two feathered stigmas $(0.15-0.2 \mathrm{~mm})$ were exposed and remained receptive for 1-2 days. In each floret, the androecium released pollen two days before the stigma became receptive, a characteristic of

Table 1. Floral attributes of terminal and axillary synflorescences of Aulonemia aristulata.

\begin{tabular}{lcc}
\hline \multirow{2}{*}{ Floral attributes } & \multicolumn{2}{c}{ Synflorescences } \\
\cline { 2 - 3 } & Terminal & Axillary \\
\hline Number of spikelets & $20-42$ & $1-3$ \\
Spikelet size (cm) & $2.4-4.2$ & $3.8-6.1$ \\
Number of fertile florets & $4-5$ & $5-9$ \\
Anther length (mm) & $0.45-0.6$ & $0.08-0.2$ \\
Anther coloration & Yellow & Pale yellow \\
Stigma length (mm) & $0.15-0.25$ & $0.25-0.45$ \\
Pollen & Present & Absent \\
\hline
\end{tabular}


protandry. Despite dichogamy, there was overlap of the male and female phases among floret. Fruiting under natural conditions $(35 \%)$ was higher than that obtained from bagged synflorescences (11.5\%). Pollen viability was on the average $90 \%$. The caryopsis was rostrate, oblong, brown, and measured (without rostrum) $0.6 \pm 0.05 \mathrm{~mm}$.

Axillary synflorescences were observed in the field from September to December 2007; they were also observed in cultivated plants. Spikelets from axillary synflorescences were straight. Anthesis and its duration were similar to those of the florets of terminal synflorescences. The three anthers were smaller than those of the terminal florets (table 1) and although pendulous and poricidal, did not produce pollen. The stigmas were bigger than those of terminal florets (table 1). Fruiting in natural conditions was $20 \%$ and caryopsis was similar to the ones of terminal florets.

Floral visitors - In the morning, florets in the male phase were visited by flies (Syrphidae) that were not considered pollinators because they had no contact with the anthers or stigma, hence the absence of pollen on their bodies.

Seed recruitment - In July 2008, $14.9 \pm 3.2$ seedlings per square meter were observed in the forest soil.

\section{Discussion}

Aulonemia aristulata is a semelparous (monocarpic) species with gregarious flowering. Although semelparity and gregarious flowering are general trends in woody bamboos (Janzen 1976), the results of this study reinforce the need to further research the life cycle of species of this group. Beyond the gregarious flowering exposed pendulous anthers and feathered stigmas present in the bisexual florets of $A$. aristulata are characteristic of grassy species, including bamboos, which are wind pollinated. In addition, the scandent habit and growth in higher parts of the canopy and the flowering in the dry season are other features of $A$. aristulata that possibly favor anemophily. Wind pollination has been demonstrated as the usual pollination mechanism in bamboos by Janzen (1976) and Huang et al. (2002).

The majority of woody bamboos display flowering intervals that can vary between three and 120 years (Janzen 1976). For Aulonemia fimbriatifolia, Clark (2004) inferred that there is a 20 -year interval. In Aulonemia aristulata, the absence of other reports on the periodicity of its flowering makes it difficult to determine this interval.

In Minas Gerais State (southeastern Brazil) populations of $A$. aristulata were blooming during the same month (August, 2007), demonstrating that this phenological event is highly synchronized (Pedro L. Viana, personal communication). The causes of the synchronized flowering and fruiting are intensely debated in the literature, and the probable evolutionary explanations for the phenomenon include predator satiation (Janzen 1976), escape from parasites (Pearson et al. 1994) and the fire cycle hypothesis (Keeley \& Bond 1999). Moreover, synchronized flowering has been referenced as an advantage assuring the efficiency of wind pollination (Waller 1993, Kelly et al. 2001, Koenig \& Ashley 2003) as seems to be the case in $A$. aristulata.

The features of the plant, the terminal inflorescences and the spikelets with bisexual flowers of $A$. aristulata agree with the description from Clark (2001). However, the presence of axillary synflorescences with pistillate flowers is described here for the first time in Aulonemia species. Moreover this is the first report of gynomonoecy in woody bamboo. This genetically determined sexual manifestation is sporadically found in Poaceae, and in the Bambusoideae; it is reported to occur in herbaceous bamboos (Olyreae tribe; Malcomber \& Kellog 2006).

Protandry in bamboo seems to be uncommon (Ramanayake \& Weerawardene 2003). The majority of the species in this group of plants are classified into two categories: gynoecium and androecium mature at the same time; and the gynoecium matures before the androecium, i.e., protogyny (John et al. 1994, Koshy et al. 2001).

Aulonemia aristulata is self-compatible as are some other studied bamboo species (Guilherme \& Ressel 2001). The overlap of the male and female phases inside the synflorescences and among florets of the same spikelet did not prevent geitonogamy and may explain the fruiting in bagged synflorescences. Pollen viability in Aulonemia aristulata was high, as reported for Ochlandra travancorica (Kennard 1955), a tropical bamboo species, but was lower than that reported for two Asian species Sinarundinaria fangiana (97\%) (Taylor \& Quin 1988) and Dendrocalamus strictus (98\%) (Nadgauda et al. 1993). The fruiting on pistilate florets can be related to the positions of the synflorescences.

The production of axillary synflorescences in individuals under natural conditions and cultivated ones with suppressed aerial portions suggests that endogenous mechanisms for the induction of flowering in $A$. aristulata may exist. In addition to environmental pressures (Seifriz 1950, Ims 1990, Mckone et al. 1998), endogenous rhythms, such as the biological clock, can induce flowering (Janzen 1976, Ims 1990). 
When bamboo seedling mortality is excessive, compositional changes in the understory vegetation can occur (Taylor \& Quin 1988). However in the studied area the seedling density of $A$. aristulata and the ability of this species to invade the open site could promote the regeneration cycle after flowering.

In conclusion, bamboo seedling recruitment observed after dieback, with the ability to colonize open areas, could promote the regeneration cycle of Aulonemia aristulata after flowering and dieback.

Acknowledgments - This research was financed by Fundação de Amparo à Pesquisa do Estado de São Paulo (05/51747-2). The authors are thankful to Dra. Maria Amélia V. Cruz-Barros and Dra. Cynthia F. Pinto da Luz for allowing access to the laboratory and for helping with the pollen analyses. The second author was supported by a Pibic /CNPq scholarship.

\section{References}

CLARK, L. 2004. New species of Aulonemia and Chusquea (Poaceae: Bambusoideae: Bambuseae) from southeastern Brazil. Revista Brasileira de Botânica 27:31-36.

CLARK, L. 2001. Aulonemia. In Flora Fanerogâmica do Estado de São Paulo (M.G.L.Wanderley, G.J. Shepherd, A.M. Giullietti, T.S. Melhem, V. Bittrich \& C. Kameyana, eds.). Fapesp-Hucitec, São Paulo, v.1, p.23-24.

CLARK, L.G., ZHANG, W. \& WENDEL, J.F. 1995. A Phylogeny of the grass family (Poaceae) based on ndhF sequence data. Systematic Botany 20:436-460.

EMBRAPA, 1999. Sistema brasileiro de classificação de solos. Embrapa, Brasília.

FILGUEIRAS, T. 1988. A floração dos bambus e seu impacto ecológico. Eugeniana 15:1-8.

FILGUEIRAS, T.S. \& SANTOS-GONÇALVES, A.P. 2004. A checklist of the basal grasses and bamboos in Brazil (Poaceae). Bamboo Science and Culture 18:7-18.

FILGUEIRAS, T.S. \& PEREIRA, B.A.S. 1988. On the flowering of Actinocladum verticillatum (Gramineae: Bambusoideae). Biotropica 20:164-166.

GIORDANO, C.V., SÁNCHEZ, R.A. \& AUSTIN, A.T. 2009. Gregarious bamboo flowering opens a window of opportunity for regeneration in a temperate forest of Patagonia. New Phytologist 181:880-889.

GRISCOM, B.W. \& ASHTON, P.M.S. 2003. Bamboo control of forest succession: Guadua sarcocarpa in Southeastern Peru. Forest Ecology and Management 175:445-454.

GRISCOM, B.W. \& ASHTON, P.M.S. 2006. A selfperpetuating bamboo disturbance cycle in a Neotropical forest. Journal of Tropical Ecology 22:587-597.

GUILHERME, F.A.G. \& RESSEL, K. 2001. Biologia floral e sistema de reprodução de Merostachys riedeliana (Poaceae: Bambusoideae). Revista Brasileira de Botânica 24:205-211.
HUANG, S.Q., YANG, C.F., LU, B. \& TAKAHASHI, Y. 2002. Honeybee-assisted wind pollinationin bamboo Phyllostachys nidularia (Bambusoideae: Poaceae)? Botanical Journal of Linnean Society 138:1-7.

IMS, R.A. 1990. The ecology and evolution of reproductive synchrony. Trends in Ecology and Evolution 5: 135-140.

JANZEN, D.H. 1976. Why bamboos wait so long to flower. Annual Review of Ecology and Systematic 7:347-391.

JOHN, C.K. \& NADGAUDA, R.S. 2002. Flower structure and function in the classification of bamboo. Current Science 82:309-1310.

JOHN, C.K., NADGAUDA, R.S. \& MASCARENHAS, A.F. 1994. Reproductive biology: an aid in the classification of bamboos. Current Science 67:5-687.

JUDZIEWICZ, E.J., CLARCK, L.G., LONDOÑO, X. \& STERN, M.J. 1999. American bamboos. Smithsonian Institute Press, Washington.

KEELEY, J.E. \& BOND, W.J. 1999. Mast flowering and semelparity in bamboos: the bamboo fire cycle hypothesis. American Naturalist 154:383-391.

KELLY, D., HART, D.E. \& ALLEN, R.B. 2001. Evaluating the wind pollination benefits of mast seeding. Ecology 138:117-126.

KENNARD, W.C. 1955. Flowering of the bamboo Guadua amplexifolia Presl in Puerto Rico. Lloydia 18:193-196.

KOENIG, W.D. \& ASHLEY, M.V. 2003. Is pollen limited? The answer is blowin' in the wind. Trends in Ecology and Evolution 18:157-159.

KÖEPPEN, W. 1948. Climatologia. Ediciones Fondo de Cultura Económica, Ciudad de Mexico.

KOSHI, K.C., HARIKUMAR, D. \& NARENDRAN, T.C. 2001. Insect visits to some bamboos of the Western Ghats. Current Science 81:833-838.

MALCOMBER, S.T. \& KELLOG, E.A. 2006. Evolution of unisexual flowers in grasses (Poaceae) and the putative sex-determination gene, TASSELSEED 2 (TS 2). New Phytologist 170:885-899.

MAMEDE, M.C.H., SOUZA, V.C., PRADO, J., WANDERLEY, M.G.L., BARROS, F. \& RANDO, J.G. (org.). 2007. Livro vermelho das espécies da flora ameaçadas de extinção no estado de São Paulo. Instituto de Botânica, São Paulo.

MCKONE, M.J., KELLY, D. \& LEE, W.G. 1998. Effect of climate change on masting species: frequency of mass flowering and escape from specialist insect seed predators. Global Change Biology 4:591-596.

NADGAUDA, R.S., JOHN, C.K. \& MASCARENHAS, A.F. 1993. Floral biology and breeding behavior in the bamboo Dendrocalamus strictus Nees. Tree Physiology 13:401-408.

PEARSON, A.K., PEARSON, O.P. \& GÓMEZ, I.A. 1994. Biology of the bamboo Chusquea culeou (Poaceae: Bambusoideae) in southern Argentina. Vegetatio 111: 93-126. 
PIVELLO, V.R. \& PECCININI, A.A. 2002. A vegetação do PEFI. In Parque Estadual das Fontes do Ipiranga: unidade de conservação que resiste à urbanização de São Paulo (D.C. Bicudo, M.C. Forti \& C.E.M. Bicudo, eds.). Secretaria do Meio Ambiente do Estado de São Paulo, São Paulo, p.75-92.

RADFORD, A.E., DICKISON, J.R. \& BELL, C.R. 1974. Vascular plant systematics. Harper \& Row Publishers, New York.

RAMANAYAKE, S.M.S.M. \& WEERAWARDENE, T.E. 2003. Flowering in a bamboo Melocanna baccifera (Bambusoideae: Poaceae). Botanical Journal of Linnean Society 143:287-291.

RAMANAYAKE， S.M.S.D. \& YAKANDAWALA， K. 1998. Incidence of flowering. Death and phenology of development in the giant bamboo (Dendrocalamus giganteus Wall. ex Munro). Annals of Botany 82:779785.
SANTOS, P.M. \& FUNARI, F.L. 2002. Clima local. In Parque Estadual das Fontes do Ipiranga: uma reserva biológica na cidade de São Paulo, São Paulo (D.C. Bicudo, M.C. Forti, \& C.E.M. Bicudo, eds.). Secretaria do Meio Ambiente do Estado de São Paulo, São Paulo, p.29-48.

SEIFRIZ, W. 1950. Gregarious flowering of Chusquea. Nature 165:635-636.

STERN, M.J., GOODELL, K. \& KENNARD, D.K. 1999. Local distribution of Chusquea tomentosa (Poaceae: Bambusoidea) before and after a flowering event. Biotropica 31:365-368.

TAYLOR, A.H. \& QIN, Z. 1988. Regeneration from seed of Sinarundinaria fangiana, a bamboo, in the Wolong Giant Panda Reserve, Sichuan, China. American Journal of Botany 75:1065-1073.

WALLER, D.M. 1993. How does mast-fruiting get started? Trends in Ecology and Evolution 8:122-123. 